\title{
ANALYZING THE MEANING OF CAPITAL FOR FARMERS
}

\author{
Fia Rahma, Iwan Triyuwono, and \\ Eko Ganis Sukoharsono \\ Economic and Business Faculty, University of Brawijaya
}

\begin{abstract}
The objective of this research is to find out the meaning of capital for farmers, by using the logical reasoning analysis of bayani, burhani, and irfani initiated by Mohammad Abed Al Jabiri (1991). The process of finding out the meaning of capital by farmers is conducted by knowing and analyzing the capital of the informants obtained through in-depth interview and observation, using three types of logical reasoning which are bayani, burhani, and irfani. Through bayani logical reasoning, the researchers got the symbol of the meaning of capital conveyed by the informants and is examined by the text approach. Moreover, through burhani logical reasoning, analysis, the researchers explored the facts, conditions, and background of the informants' lives. The final step of data analysis in this research was gained through the irfani logical reasoning approach that was applied by the synchronization process of all information obtained using the researchers' clarity of conscience to be able to draw a comprehensive conclusion. This research found the meaning of capital for Smartani group farmers is combination material capital and the determination to apply the science and experience in managing the resources they own well, by maintaining relationship with colleagues and community for the continuity of the farming business.
\end{abstract}

Keywords: capital, farmers, bayani, burhani, irfani

\section{INTRODUCTION}

Indonesia is known as an agricultural country, where agriculture plays a strategic role in the process of economic development ${ }^{1}$ (Johnston and Mellor, 1961). However, as time goes on, the Indonesian agricultural sector seems to be marginalized, ostracized, and considered less bona fide. This is proven in the lack of interest of the youth to preserve the "culture" of farming which is full of values, customs, and national identity ${ }^{2}$.

The downfall of the agricultural sector was aggravated by the fact that the increase of food production done by the Ministry of Agriculture, was inversely proportional to the increase of poverty dominated by farmers, caused by several factors, from lack of capital and small landlord (Amir et al., 2014). The researchers underline that the downfall of the agricultural sector is caused by capital factors. Capital is part of an accounting symbol, which is defined as the amount of money or goods used in a business. However, the meaning

The ministry of agriculture in the performance report Kementan 2015 stated that the agricultural sector was the second largest contributor to GDP $(13,49 \%)$

2 The ministry of agriculture on its performance's report in 2015 stated, the employment in the agricultural sector within the last five years has been reduced as much as $10,08 \%$ 
cannot be done in general. According to (Evans, 2004), there is a close relationship between language and culture, in which every meaning has to be associated with the culture of meaning. Even the practice of accounting appears and is affected by the social processes where it is applied (Riyadh et al., 2017).

In the context of agriculture, if the definition of capital used is only limited to money and goods, it is difficult to alleviate farmers from the downfall. However, when it is seen from a farmer's perspective, is it true that they have difficulties due to lack of capital, and what is actually the meaning of the capital by them? This makes the researchers interested in knowing more about the meaning of capital by farmers, so that it can be an alternative solution in improving their perceptions and steps.

The concept of independent capital is being applied by various groups of farmers, one of them is the Smartani group, which is located at Jabung village, Talun District, Blitar Regency. The Smartani group is an informal group, (not in the form of an official group like any farmer group) which becomes a forum for farmers to exchange experiences, get solutions, as well as advices from practitioners and competent parties. The diversity of farmers who join Smartani provides an image of the diverse types of capital used by farmers. This diversity makes the researchers interested in exploring the meaning of capital by the Smartani group.

\section{METHOD}

Islam provides guidance not only in the routine of worship to God, but also in the context of fulfilling the needs of human life in the world (Mais et al., 2017). The Islamic paradigm is a paradigm that prioritizes the integrity of the concept, covering the aspect of humanity, culture, spirituality, and divinity (Triyuwono, 2015). The method that allows the researchers to interpret, explain and understand the reality holistically and without always based on numbers, variables, hypotheses or artificial tools is a qualitative methodz (Bodgan and Taylor, 1975). The main data collection techniques in qualiative research were obtained through observation and in-depth interview.

The choice of informants was done by a snowball technique, to discuss the social communication patterns of a particular community. The informants in this research are Mr. Ma'sum as Smartani supervisor, Mr. Endik as the chairman of Smartani Blitar, the farmers represented by Mr. Mujib, Mr. Hakam as a representative of young farmers, Mr. Riyo as a representative of farmers with various types of businesses, and Mr. Karman as a successful village farmer with independent capital. The main interviews questions in this research are what is the informant's perceptions of capital? (bayani), is the capital used by the informant according to the background status? (burhani), and how is the management of capital used by informant? (irfani).

The research process was done by using logical reasoning analysis initiated by Islamic research leader Muhammad 'Abed al-Jabiri (1991) in his work Bunyah al Aql al Arabi about three logical reasoning techniques which are bayani, burhani, and irfani. Bayani logical reasoning can be interpreted as text, logical reasoning. Bayani logical reasoning by some groups is considered less dynamic in following the development of civilization because it only relies on the text (Musliadi, 2014). Burhani logical reasoning comes from human intellectual power (Al Jabiri, 1991). The critics of this paradigm assumed that the burhani overestimates the position of reasoning so that it cannot explain other forms of reality such as soul, mentality, taste, etc (Widodo, 2007). Irfani logical reasoning considers that knowledge can be 
gained through life experiences about the existence of God without having to wait for the text to inform him (Damanhuri, 2016). According to Al Jabiri, bayani, burhani, and irfani logical reasoning are used together. However, in this research, the researchers tried to combine the use of all three as an analytical tool to gain the essence of the whole meaning of capital (Abdullah, 2001).

The role of bayani logical reasoning in this research is the foundation of data analysis. Through bayani logical reasoning, the researchers got the symbol of the meaning of capital conveyed by the informants and is examined by the text approach. Moreover, through burhani logical reasoning analysis, the researchers explored the facts, conditions, and background of the informants' lives. The final step of data analysis in this research was gained through the irfani logical reasoning approach that was applied by the synchronization process of all information obtained using the researchers clarity of conscience to be able to draw a comprehensive conclusion.

\section{RESULTS AND DISCUSSION}

\section{Farming: The Effort of Gaining the Capital Business}

Mr. Endik Mashudi, as Smartani's supervisor, explained the capital used in farming as follows:

"I also have mixed capital, I use my own money, but some of them are from the bank." Through bayani logical reasoning, after conducting an interview with Mr. Endik Mashudi as Smartani's supervisor, the researchers get the presence of a symbol of the meaning of capital stated by him through the phrase "mixed capital", which the researchers interpret it as a combination of capital from personal pocket and loan capital from bank.

Then the researchers use burhani logical reasoning to explore the facts behind the answer of mixed capital by Mr. Endik. In the next conversation, when the researchers asked about the process of his farming business, Mr. Endik stated that the farming develop due to input and discussion from Smartani's supervisor, Mr. Ma'sum. From Mr. Endik's answer, the researchers get the important role of experience shared by Mr. Ma'sum with Mr. Endik to develop his agricultural business.

Moreover, the researchers ask about what is the important role in running the business according to Mr. Endik. In a conversation, Mr. Endik said:

"In life, we must continue to learn, if not, we will not go forward. It is like science. It is not used for a long time then it will be forgotten, right?"

Implicitly, in his statement Mr. Endik seems to want to emphasize the importance of the role of science and the desire to continue to learn. From the background of Mr. Endik who grew up in a large farmer's family, it can be seen that the experience gained by Mr. Endik is actually not only from sharing done with Mr. Ma'sum alone, but also based on personal experience and family experiences that have previously engaged in agriculture. In addition, when the researchers conducted an interview, he was finishing his study in agriculture as well.

The researchers use irfani logical reasoning in order to understand the meaning of the capital that Mr. Endik really wants to convey. Mr. Endik's statement on capital In fact does not refer to something that is material, but is more focused on knowledge and experience. The researchers come to the conclusion that the meaning of mixed-up capital, according to Mr. Endik is a combination of material with knowledge and experience that is always practiced and developed. 


\section{Farming with Respectfulness}

When the researchers explored information about the meaning of capital by Mr. Mujib, he answered:

"Haha, I am just giving my dengkul, all the capital comes from the boss, (glanced at Mr. Endik)"

Through bayani logical reasoning, the researchers get the symbol of the meaning of capital in

the form of "giving my dengkul" by Mr. Mujib. Dengkul in Javanese means knee, so giving his dengkul as capital can be interpreted as capital workforce.

After getting the symbol of the meaning of capital by Mr. Mujib, the researchers then do a factual analysis on the background of why Mr. Mujib stated his capital as "knee capital".

The collection of factual analysis by the researchers is done by using burhani logical reasoning. Mr. Mujib's statement regarding his agricultural business done by using knee capital is continued with an explanatory sentence as follows:

"I only have capital in the form of panggonan and labor, then if there is a problem, I will go to the boss."

According to Mr. Mujib's statement, a conclusion can be drawn about what Mr. Mujib means as knee capital is a panggonan, which means a place or land in Javanese, and labor. This means that Mr. Mujib has a different understanding of the meaning of knee capital in general, because he included land to the meaning of of labor. Mr. Mujib is a village farmer with limited land. However, Mr. Mujib does not give up and was not discouraged. He joined Smartani to get better business results. Throughout the conversation with Mr. Mujib, the researchers found no complaints about the small comings, in fact what appeared was a peaceful soul. This is in line with the statement of Mr. Mujib that he runs a business with what he has, not making it up for the sake of fulfilling family needs.

After gaining some facts related to farming conducted by Mr. Mujib, the researchers use the role of conscience to draw conclusion through irfani logical reasoning. The researchers then conclude that what was meant by Mr. Mujib as knee capital is labor and land capital with persistence and run a farming business steadfastly.

\section{Farming with Recklessly Brave Capital}

There are two possibilities that can happen when someone falls to the lowest point in his life. Getting worse because they continue to regret their fate, or stand up with all the effort because they actually have the potential to find solutions and seek a better life (Riyadh et al., 2017). That is how the initial description of the agricultural business done by Mr. Hakam, who claims to have only the reckless capital in farming.

"For me, the most important thing to be just being "recklessly brave", in terms of place, labor and other capital can be solved later, the important thing is to be recklessly brave if you want to do a business", said Mr. Hakam.

In Mr. Hakam's statement through bayani logical reasoning, the researchers get the existence of a symbol of the meaning of capital, which is expressed in terms of recklessly brave capital. The recklessly brave meaning in the Great Dictionary of Indonesian Language is being hardhearted or overly brave and not thinking for a long-term in doing something.

The effort to find the meaning of "recklessly brave capital" by Mr. Hakam is continued by using burhani logical reasoning. Then, the researchers find out about the background of Mr. Hakam's life. Back then, Mr. Hakam worked outside Java, but the results were zero. He 
then decided to farm on land owned by his parents. In the beginning, Mr.

Hakam only did farming as usual, but the results obtained could not fulfill his basic needs. Finally, Mr. Hakam met and studied with Mr. Ma'sum. To cover up material capital needs, Mr. Hakam bravely applied for a loan to the bank. Meanwhile, to meet the needs of the workforce, he empowered the community around his environment to help his farming business.

After obtaining some facts through burhani logical reasoning, the researchers understand what was meant by Hakam as recklessly brave capital using irfani logical reasoning. The recklessly brave capital by Mr. Hakam is not just brave to go forward without thinking, like the meaning in general. For Mr. Hakam, recklessly rave capital means trying with determination, along with certain strategies to maximize the results and benefits of farming.

\section{Outsmarting the Farmers' Capital}

"Yes, Ms., for the next intercropping, I plant them also per plot. While outsmarting the money," said Mr. Riyo. Through bayani logical reasoning, the researchers found a statement about the meaning of capital by Mr. Riyo, which is a capital that is tricked. Based on this information, the researchers interpret that outsmarting capital means using reason to find or manage capital. However, Mr Riyo's statement is still limited to the meaning that the capital used by him is merely money capital.

To search for the essence of the meaning of capital by Mr. Riyo, the researchers do the analysis using burhani logical reasoning, which is gathering information, facts, and seeing the surrounding conditions experienced by Mr. Riyo. The initial fact is that besides farming, Mr. Riyo also has fish and some goats. Based on the researchers' observation, Mr. Riyo is a hard worker and persistent. This can be seen in the condition of his house which is clean and tidy even though every day he has to do a lot of work. The reflection of Mr Riyo's hardworking and persistent nature also shows his willingness to continue to learn. He learns to make his own portable seedling shade, directed by Mr. Endik.

The business run by Mr. Riyo is a real example of the term in investment management by "don't put all your eggs in one basket". In this case Mr. Riyo tries to maximize the role of his resources. When farming, raising goats and fish can be run together, then the resources and time he has will be used effectively and efficiently. So, if one of the income sources suffers a loss, another income source can still be used to cover the needs.

In the early explanation through bayani logical reasoning, what appears from $\mathrm{Mr}$ Riyo's statement about the meaning of capital is only about material. However, after analyzing several facts found using burhani logical reasoning, the researchers find a way to interpret the meaning of capital that Mr. Riyo meant is apparently not only about material. Thus, by using irfani logical reasoning, the researchers can understand what is meant by Mr. Riyo as capital is the willingness to try as much as possible to meet the needs. He uses logical reasoning to find the best way to meet some needs in the same period of time, as well as with the resources he owns.

\section{Capital from "Sing Ngecet Lombok"}

On this occasion the researchers have the opportunity to talk with Smartani member who has become a successful and independent farmer, Mr Karman. In his statement related to capital, Mr. Karman said:

"People like me just accept the things that I deserve from "sing ngecet lombok"” 
From the discussion between the researchers and Mr Karman, through bayani logical reasoning the researchers get a symbol of the meaning of capital in the form of an expression of capital from "sing ngecet lombok". The phrase "sing ngecet lombok" or in bahasa Indonesia means "who gives the color of chili" refers to Allah Swt. The next researchers' effort is to find the meaning or form of capital by Mr Karman as the capital bestowed by the Almighty, through burhani logical reasoning.

Through burhani logical reasoning, the researchers analyze and collect some facts to find out the meaning of the capital by Mr Karman. He is a successful village farmer, who is known to be generous in helping local residents to get additional income. With the participation of others who help his agricultural business, it makes Mr. Karman feel that he is responsible for their life needs. He acknowledges that attitude as an effort to strengthen relationships between farmers. So that he does not consider the farmers who help him as subordinates or workers but as brothers.

Because of the good treatment, Mr. Karman also gains another benefit, which is when on another occasion he needs help from the workforce, the community gladly wants to help him.

"Thank you Allah, we will not be worried if someday we will need anyone's help.

Without begging for the help, people will come by themselves. Sometimes they also invite their siblings too. Sometimes they are from another village." If it is associated with capital grouping according to (Zohar and Marshall (2004) the position of maintaining brotherhood relations between farmers can belong to the social capital group. Social capital relates to the concern for relations between people, as the question emphasized in developing this capital is "what I feel". The manifestation of the development of social capital in farming effort by members of the Smartani group is by always trying to maintain good relationship between farmers and local residents. This fact has a good impact on the sustainability of the farming business that they do.

After gathering the facts related to the conditions and background of Mr. Karman, the researchers use irfani logical reasoning to draw conclusion about what was meant by $\mathrm{Mr}$ Karman with the capital that comes from "sing ngecet lombok". In this process, the researchers come to the conclusion that the capital of "sing ngecet lombok" by Mr Karman refers to maintaining relationship with fellow human beings which is brotherhood relations (ukhuwah). Based on his statement, it is proven that because of keeping ukhuwah with the surrounding community, Mr Karman can gain success in running a farming business.

\section{Drawing Conclusion of the Meaning of Capital}

Drawing conclusion to obtain results that are general and cover all findings of the meaning of capital stated by the informants is done by the researchers using irfani logical reasoning. The first step is begging forgiveness to Allah SWT, and asking for clarity in discovering the meaning of capital both implicitly and explicitly. Irfani knowledge is knowledge that can be gained through direct experience. The researchers conduct identical activities to the informants,' activities by farming in the home grounds of the researchers' parents, as well as taking care of several animals owned by the researchers' parents. These activities are conducted by the researchers by always asking for the knowledge from Allah SWT, to be able to participate in experiencing how the farmers who are members of Smartani never discus the difficulties and downfall of the agricultural sector that is widely known in the community.

Thank you Allah, after some time, the researchers can feel how the informants feel. 
This happens when the chickens that the researcherss take care of suddenly die without even a single one left. In the village where the researchers live, there is a season called " aratan season" where livestock, especially chickens, often dies suddenly. In the midst of the sadness that the researchers feel, suddenly the researchers remember a verse of the Qur'an, which is Surah Ali Imran verse 92 which means as follows:

"Never will you attain the good [reward] until you spend [in the way of Allah] from that which you love. And whatever you spend - indeed, Allah knows about it. " (Surah. Ali Imran: 92)

It is truly the Holy of Allah, no one can know anything unless it has been taught by Him. Allah is All-Knowing, while the absorption of His teachings by humans is very limited. The researchers have finally been able to understand how Smartani farmers can feel at ease even though the agricultural business they are engaged in suffers losses, because their main purpose is not in the form of material, but worship to reach the pleasure of Allah. So, after doing business to the fullest, what can be done by creatures is to surrender to Allah the Lord of All Nature. So that whatever happens later, both profit and materially loss do not become a problem for them. They also do not despair and continue to trying their best steadfastly. It is because the actual measure of success lies not in material benefits, but in useful interpretation.

\section{The Map of Concept of Capital Meaning by Farmers}

After conducting various analyzes of the meaning of capital, starting from the logical reasoning of bayani, burhani, and irfani, the researchers draw conclusion, which are the existence of harmony between the background, existence, and environment of the farmers with the meaning of capital expressed. For Mr. Endik, who has an educational background in agriculture, capital is interpreted as the implementation of the knowledge that has been obtained, whether it is from family, other people, and formal education at the university. Mr. Mujib as a modest farmer interprets the capital as having labor and land. Meanwhile Mr. Hakam who has undergone a downfall in business at a young age interprets capital as a strong determination to obtain success. Mr. Riyo, as a farmer as well as breeder and fish cultivator, interprets capital as the ability to manage his resources as well as possible. $\mathrm{Mr}$ Karman, who is a successful village farmer, interprets capital as the result of strong brotherhood relations (ukhuwah) with the surrounding community.

Thus, the conclusion can be drawn that for Smartani group farmers, capital is not always about material. The capital applied in the Smartani group is manifested in the determination to apply the knowledge and experience in managing the resources that are owned as well as possible, with the effort of maintaining a kinship with the surrounding community who have the same profession for the continuity of the farming business.

\section{The Comparison of Meaning of Capital: Conventional vs. Research Results}

Theoretically, if we discuss about capital, the main reference will be a group of materials used in the business. It is like the understanding of capital in the Indonesian Dictionary, which is "money or goods used as a basis for work". In the scope of agriculture, farming capital is defined as goods or money, which with other production factors such as land and labor can be used to produce new goods (Mubyarto, 1989). Meanwhile, according to the (Kadarsan, 1992) farming capital is a production factor that is provided, processed, and controlled in a farming business either it is on a large or small scale. Overall capital is interpreted as something material. However, in this research, the researchers found that the 
meaning of capital for Smartani member farmers such as the practice of knowledge and experience, determination, maximizing processing resources, and brotherhood relations (ukhuwah) between people. Therefore, capital turns out to not only be interpreted as something tangible and can be calculated certainly (Khairi, 2013), but also developed other capital terms such as intellectual, social, and spiritual capital.

Zohar and Marshall (2004), in their book entitled Spiritual Capital, stated that spiritual capital has a greater contribution than the other three types of capital, which are physical, intellectual, social, and spiritual capital. It is even said that the other three types of capital cannot be used optimally if they are not based on spiritual capital. However, it turns out that in this research the capital applied by Smartani group farmers has various proportions and is related to the background and conditions being experienced by the farmers concerned.

Mr. Endik, with his background in agricultural education, tends to use intellectual capital he has compared to other types of capital. Mr. Mujib, as a small farmer, makes physical capital in the form of labor and land as the main pillar of his farming business. A modest farmer with various types of businesses such as Mr. Riyo prioritizes the combination of the four types of capital on an ongoing basis in the form of the use of logical reasoning to manage all the resources owned to maximize the results obtained and achieve peace of mind in running the business. For Mr. Hakam, who had fallen up in the capital business, the priority is spiritual capital that is applied in the form of determination and steadfast in the business. Meanwhile, Mr Karman, as a successful village farmer, prioritizes social capital in the form of kinship between farmers and the surrounding community.

Besides the differences in the level of capital and its portion in determining business success, there are also other differences between the results of this research and the statements of Zohar and Marshall (2004) related to the understanding of spiritual capital. According to Zohar and Marshall (2004), spiritual capital can be realized by bringing back spirituality in life without having to return to religion. Spiritual capital is defined as the human ability to answer fundamental questions that exist in the brain through God Spot (Zohar and Marshall, 2004). According to them, religion is only a set of rules and beliefs that are externally charged. Thus, even a non-religious person can have a high level of spirituality than a religious person (Zohar and Marshall, 2004).

Meanwhile, in this research, the researches found a close relationship between religion and spiritual capital used by Smartani farmers. Even beyond the limitation that is related with spiritual capital, the level of religiosity can also influence the use of physical, intellectual, and social capital in business. For example, Mr. Endik's statement that practices his knowledge for the welfare of his assisted farmers refers to religious teaching to practice his knowledge. Mr. Mujib, with all his deficiencies, continues to strive with all the resources he has. Mr. Hakam, who has a downfall in running the business, tries not to despair and look for the best way to achieve success. Mr. Riyo who has always been persistent to continue learning to develop a farming business as well as possible. Mr. Karman, who always tries to maintain good relationship with the people associated with him. Everything refers to religion. Spiritual capital includes disclosures of God Consciousness, transcedental awareness, honesty, self contemplation ability and sincere love (Sukoharsono, 2018). Therefore, the level of one's spirituality is influenced by religion (Mais et, al., 2017). A person who understands religion as well, then he/she will be able to control and put everything in proportion (Sukoharsono, 2010). Not only in the aspect of spiritual capital, but also in the aspect of physical, intellectual, and social capital. 


\section{CONCLUSION}

The capital that is still associated with material aspects, in fact has a different meaning for Smartani member farmers. After conducting some logical reasonings based on the reasoning techniques initiated by Mohammed Abed Al Jabiri, which are bayani, burhani, and irfani logical reasoning, it can be concluded that the capital applied in the Smartani group is a combination of material capital with the determination to apply the knowledge and experience in managing resources as well as possible, and the effort of maintaining kinship with the surrounding community who has the same profession for the continuity of farming. This understanding of capital can lead farmers to religiousism. The farmer's steadfastness, besides being a determinant of big or small the income is, is also a determinant of income that is beneficial and blessed.

This research can provide theoretical and practical implication for interested parties. Theoretically, the results of this research can be used to develop accounting researches, especially in the agricultural sector and the development of accounting researches with a nonpositive paradigm. Practically, the results of this research can contribute to farmers by providing a means to increase understanding of types of capital and independent agriculture. For academicians, the results of this research can provide knowledge that accounting cannot only be interpreted in terms of material but also spiritual. 


\section{REFERENCES}

Abdullah, M.A., 2001. Al-Ta'wil Al-'Ilmi: Ke Arah Perubahan Paradigma Penafsiran Kitab Suci. Al-Jami'ah 39, No. 2, 359-391.

Al Jabiri, M.A., 1991. Bunyah al Aql al Arabi. Al Markaz al Tsaqafi al Arabi, Beirut.

Amir, V., Mulawarman, A.D., Kamayanti, A., Irianto, G., 2014. Gugurnya Petani Rakyat: Episode Perang Laba Pertanian Nasional. Universitas Brawijaya Press, Malang.

Bodgan, R., Taylor, S.J., 1975. Introduction to Qualitative ResearchMethode. John Willey and Sons, New York.

Damanhuri, 2016. IjtihadHermeneutis Eksplorasi Pemikiran Asy-Syafi 'i dari Kritik Hingga Pengembangan Metodologis. IRCiSoD, Yogyakarta.

Evans, L., 2004. Language, Translation, and the Problem of International Accounting Communication. Accounting, Auditing, and Accountability Journal 17 (2), 210-248.

Johnston, B.F., Mellor, J.W., 1961. The Role of Agriculture in Economic Development. American Economic Review 51 (4), 566-593.

Kadarsan, H.W., 1992. Keuangan Pertanian dan Pembiayaan Perusahaan Agribisnis. Gramedia Pustaka Utama, Jakarta.

Khairi, M.S., 2013. Memahami Spiritual Capital dalam Organisasi Bisnis Melalui Perspektif Islam. Jurnal Akuntansi Multiparadigma 4, No. 2, 286-307.

Kurniawan, R., 2012. Valuasi Aset Biologis: Kajian Kritis atas IAS 41 mengenai Akuntansi Pertanian (Skripsi). Universitas Brawijaya, Malang.

Mais, R.G., Sukoharsono, E.G., Rahman, A.F., Mulawarman, A.D., 2017. Corporate Social Responsibility: Actualization of Value of Jaudatul Adaa (Well Ending) in Islamic Banking. The International Journal of Accounting and Society 25 (2), 17-30.

Mubyarto, 1989. Pengantar Ekonomi Pertanian. LP3S, Jakarta.

Musliadi, 2014. Epistimologi Keilmuan Dalam Islam: Kajian Terhadap Pemikiran M. Amin Abdullah. Jurnal IImiah Islam Futura 13 (2), 160-183.

Riyadh, H.A., Sukoharsono, E.G., Alfaiza, S.A., 2017. A Critical Analysis of Iraqi

Accounting Thought: Some Thought on the Search for Better Understanding of Accounting in Practice. International Journal of Applied Business and Economic Research 15 (22), 17-33.

Sukoharsono, E.G., 2018. Sustaining a Sustainability Report by Modifiying Triple Bottom Line to Pentaple Bottom Line: An Imaginary Research Dialogue. Presented at: the International Interdisciplinary Studies Seminar on Environmental Conservation and Education for Sustainable Development, $14^{\text {th }}-15^{\text {th }}$ November 2018, Malang, Indonesia

Sukoharsono, E.G., 2010. Metamorfosis Akuntansi Sosial dan Lingkungan: Mengkonstruksi Akuntansi Sustainabilitas Berdimensi Spiritualitas. Unpublished Naskah Pidato Guru Besar Faculty of Economics, University of Brawijaya, December

Triyuwono, I., 2015. Akuntansi Malangan: Salam Satu Jiwa dan Konsep Kinerja Klub Sepak Bola. Jurnal Akuntansi Multiparadigma 6, No. 2, 290-303.

Widodo, S.A., 2007. Nalar Bayani, Irfani, dan Burhani. Hermeneia Jurnal Kajian Islam Interdisipliner 6, No. 1, 65-92.

Zohar, D., Marshall, I., 2004. Spiritual Capital: Wealth We Can Live By. Berret-Koehler Publisher, San Fransisco. 
Vol.27, No.1 April 2019 